\title{
Refleksologi kan bedre urinveissymptomer hos pasienter med multippel sklerose
}

Utvalg og oversettelse ved

Liv Merete Reinar

Illustrasjonsfoto: Colourbox

\section{Hva er effekten av og sikker- heten ved å tilby refleksologi til pasienter med hvilken som helst tilstand?}

\section{SYSTEMATISK OVERSIKT}

Studier som ble valgt sammenliknet refleksologi med ingen eller annen terapi til pasienter med hvilken som helst tilstand. Studiene skulle rapportere symptomer, psykologisk velvære, livskvalitet eller opplevelsen av å motta refleksologi. Studiene skulle også være av minimum moderat metodisk kvalitet i henhold til krav satt av «US Preventive Services Task Force». Ekskluderte studier evaluerte kombinasjonsterapier med refleksologi og andre terapier, yngre deltakere ( $<18$ år), $<$ ti deltakere per gruppe, eller at forfatteren ga for lite informasjon om effektmål. Utfallsmål var urinveissymptomer, paraesthesia, muskestyrke, spastisitet, lungefunksjon, menopausesymptomer, angst, depresjon, livskvalitet, symptombedring ved irritabel tarm, leggomkrets og bivirkninger.

\section{METODE}

Søk i medline, Cochrane Library, ProQuest Medcal Bundle, Evidence Based Medi- cine Reviews SCOPUS, Chinese electronical periodical services, og Wangfane fra 1996 til 2007 for kontrollerte studier publisert på engelsk og kinesisk. Fem randomiserte, kontrollerte studier (RCT) (n=251) møtte inklusjonskriteriene. De sammenliknet refleksologi med leggmassasje, ikke-spesifikk fotmassasje, avslappende refleksologi eller hvile.

\section{HOVEDRESULTATER}

Én enkelt studie $(n=39)$ fant at refleksologi bedret urinveissymptomer mer enn leggmassasje hos pasienter med multippel sklerose (effektstørrelse -0,9, 95 prosent KI -1,6 til -0,2). Andre
Resultatene fra denne systematiske oversikten fra Wang og medarbeider vil være skuffende lesing for sykepleiere som allerede bruker refleksologi i sin kliniske praksis, særlig i lys av ønsket om å praktisere kunnskapsbasert. Likevel stimulerer dypere analyse av konklusjonene til kritisk refleksjon. Selv om rutinemessig tilbud ikke blir anbefalt er det ikke nødvendigvis kontraindisert å tilby refleksologi til den individuelle pasient. Men det må være basert på vurdering av klinisk behov og pasientens preferanser. Sykepleiere må sikre at tilbud om refleksologi er i tråd med lokale retningslinjer for organisasjonen de praktiserer i. Disse bør tydeliggjøre om refleksologi er et behandlingstilbud eller en del av sykepleien. Bruk av refleksologi kan være en del av sykepleien hvis det møter et sykepleiebehov, særlig behov som er vanskelig å møte med effektiv behandling.

Oversikten til Wang og medarbeidere fant at refleksologi ikke var effektivt for velvære eller emosjonelt stress, men andre har funnet at det er effektivt mot stress (støttet av fysiologiske endringer) (1). Selv om refleksologi har begrenset effekt kan det være en mulighet for sykepleiere til å bruke spesifikk tid i ro sammen med pasientene. Slik «kvalitetstid» kan fremme kommunikasjon, ett viktig aspekt $i$ et terapeutisk forhold.

Skeptikere vil med rette stille spørsmål om refleksologi har samme effekt som «caring touch» sammen med fotmassasje. Selv om oversikten til Wang antyder at det er noe spesielt og annerledes med refleksologi så bør sykepleiere være tilbakeholdende.

1. Hodgson N, Andersen S. The clinical efficacy of reflexology in nursing home residents with dementia. J Altern Complement Med 2008;14:269-75

2. Angela Avis, MBE, RGN, MA

Oxford Brookes University, Oxford, UK 
studier fant ingen forskjell mellom grupper på paraesthesia, muskelstyrke eller spastisitet på pasienter med multippel sklerose; lungefunksjon på pasienter med bronkial astma; hetetokter, nattesvette, angst, depresjon eller livskvalitet hos kvinner i menopausen; eller på leggomkrets hos gravide med fotødemer. Ingen studier rapporterte bivirkninger.

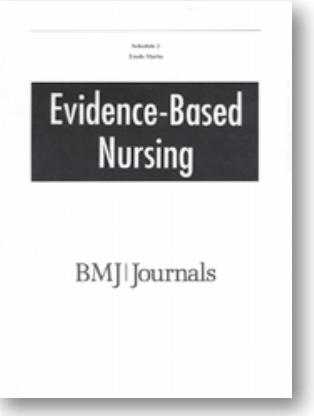

\section{KONKLUSJON}

Refleksologi bedret urinveissymptomer hos pasienter med multippel sklerose, men var ikke effektivt for andre utfall for en rekke tilstander.
Sammendrag fra: Wang MY, Tsai PS, Lee $\mathrm{PH}$, et al. The efficacy of reflexology: systematic review. J Adv Nurs 2008;62:512-20.

Korrespondanse: Dr P-S Tsai, Taipei Medical Universituly, Taipei, Taiwan; ptsaiatmu.edu.tw

Finansiering: Departement of Health, Executive Yuan, Taiwan

«Clinical impact rating»: komplementær behandling 4/7; allmennpraksis 6/7. 